\title{
Renewable Energy in Flanders. Current Situation, trends and potential for spatial planning
}

\author{
X.B. Lastra Bravo ${ }^{1, *}$, T. Steenberghen ${ }^{2}$, A. Tolón Becerra ${ }^{1}$, B. Debecker ${ }^{2}$ \\ ${ }^{1}$ University of Almería, Almería, Spain \\ ${ }^{2}$ Katholieke Universiteit Leuven, Leuven, Belgium \\ * Corresponding author. Tel: +34 950015902, Fax: +34 950015491, E-mail: xlastra@ual.es
}

\begin{abstract}
In its energy policy, the European Union (EU) sets the target of a 13\% share of renewable energy sources (RES) for Belgium. Several instruments have been implemented to reach this target. The objective of this study is analyze those instruments and it effectiveness and efficiency. To tackle this objective, we first analyze the current status of RES in Flanders. Second, we compare the situation in Flanders to the national situation in Belgium and to the other EU member states. Then, we analyze the potential of each type of RES. Finally, we discuss the opportunities and problems of RES related to spatial planning.

In Flanders, the main application of renewable energy is electricity production, of which the main source is biomass. An aspect of the Flemish energy policy worth mentioning is the green certificate system, which has stimulated the development of renewable energies. However, a greater effort to regulate this market and to decrease the cost of kWh produced has proven to be necessary.

The RES-electricity share of total consumption has increased by 3.2\% between 1994 and 2008. But, compared to others EU countries, the share of RES to gross inland consumption in Flanders is small. Large-scale facilities are necessary to reach the EU targets. The development of large wind, biomass and solar projects is suggested as the preferred option for Flanders.
\end{abstract}

Keywords: Renewable energy sources, EU Policy, Spatial planning, Flanders

\section{Introduction}

The term 'renewable energy source' (RES), which is closely linked to sustainable development, is defined as any sustainable resource available in the long term in a simple long-lasting manner, found at a reasonable cost and applicable for any task without causing negative effects [1,2,3]. Several technologies are available for the production of clean, efficient and reliable energy from long-term renewable resources, such as wind, sun, water, biomass and biogas, tides and waves, hydrogen and geothermal energy $[1,4]$.

Worldwide development of RES is currently limited by the high cost for development and implantation, uncertainty on local impact, insufficient funding for research and poor institutional and economic agreements, and limited availability of technological and economic know-how [5,6]. These problems can be solved by technical, economic, market, social and institutional means [2,6], but mainly through policies that incentivize and improve RES access to the power market $[1,7]$.

The annual business volume of the renewable energy market in the European Union (EU) is 15 million $€$, equivalent to half of the world market, in which the EU is a leading exporter [8]. Furthermore, the EU is the second largest power market in the world (450 million consumers), but the contribution of RES continues to be relatively small, only $6 \%$ in 2000 $[9,10]$. In this context, at the proposal of the Commission, the European Council approved the so-called 20-20-20 goals [11,12]. The RES goals are 20\% of EU energy consumption from RES and an increase in the share of biofuels to $10 \%$ of the transport fuel mix consumed in the EU by 2020. The EU target set for Belgium is an RES share of 13\% [13]. The Belgian National Action Plan, published in November 2010, establishes the Flanders targets related to EU targets and the strategies to reach it in this sense. 
The purpose of this study is to analyse the instruments implemented in Flanders to reach the EU RES target, and their effectiveness and efficiency. The analysis was done using available statistical data, and improved by interviews with a large number of people related to renewable energies in Flanders.

\section{Renewable energies in Flanders}

Solar water heaters, solar panels and wind turbines are becoming well established [14]. However, Flanders produces a lot more renewable energy from many lesser-known sources, such as biomass, biogas and even from waste. In the last years, the energy from wind and sun went through a larger development than the others types (Table 1). In Flanders, the main application of RES is electricity generation, and two-thirds of this comes from biomass [15].

Table1. Renewable energy inventory of Flanders (2005-2008).

\begin{tabular}{|c|c|c|c|c|}
\hline Green electricity production (TJ) (net) & 2005 & 2006 & 2007 & 2008 \\
\hline Hydropower & 8.2 & 7.5 & 9.9 & 13.0 \\
\hline Wind energy & 556.0 & 855.0 & $1,013.0$ & $1,198.8$ \\
\hline Solar (PV) & 4.7 & 11.2 & 20.0 & 120.3 \\
\hline Waste incineration & 574.3 & 749.5 & 922.0 & 961.6 \\
\hline Biomass & $1,537.5$ & $2,904.5$ & $3,033.0$ & $3,942.2$ \\
\hline Biogas & 800.7 & 624.2 & 907.5 & 954.4 \\
\hline Total green electricity & $3,481.3$ & $5,151.8$ & $5,905.4$ & $7,190.3$ \\
\hline Gross electricity consumption (GEC) & $210,327.8$ & $216,441.1$ & $217,430.6$ & $215,960.9$ \\
\hline Net green electricity / GEC (\%) & 1.7 & 2.4 & 2.7 & 3.3 \\
\hline Green heat production (TJ) & 2005 & 2006 & 2007 & 2008 \\
\hline - by CHP plants & & 2,153 & 3,074 & 3,252 \\
\hline - by plants that produce only heat & & 6,446 & 6,704 & 6,960 \\
\hline Total green heat production & & 8,598 & 9,777 & 10,213 \\
\hline Total heat & & 503,266 & 466,569 & 486,359 \\
\hline Green heat / total heat (\%) & & 1.7 & 2.1 & 2.1 \\
\hline Biofuels consumption (TJ) & 2005 & 2006 & 2007 & 2008 \\
\hline Biofuels for transport & 0 & 0 & 1,996 & 2,179 \\
\hline Total road transport consumption & 176,477 & 176,462 & 179,030 & 180,630 \\
\hline $\begin{array}{c}\text { Biofuels / energy consumption in road } \\
\text { transport (\%) }\end{array}$ & 0.0 & 0.0 & 1.1 & 1.2 \\
\hline
\end{tabular}

The Flemish Energy and Natural Resources Policy of 2004 and 2009 stipulated that by 2010, $25 \%$ of the electricity supplied in Flanders had to be generated by RES and cogeneration. Specifically, for renewable energy from wind, biomass and solar, the energy policy defines a $6 \%$ target of. The remaining 19\% must be generated by Cooling Heating and Power Plants (CHP) [16]. The current government (2009-2014) decided to continue this policy until a new target for 2020 was drafted. Flanders finalized its Action Plan, and integrated it, and in consultation with the Federal Government, it was also integrated in the action plans of the other regions.

For the Flemish Government, biofuels are not a priority due to current problems with their production and their impact on agriculture, biodiversity, forests and land use changes. The 
Flemish Government is looking for other alternatives and new advances in the production of second and third generation biofuels.

\subsection{Location of Renewable Energy Facilities in Flanders}

Wind turbines, especially large-scale, are usually located near urban or industrial centres, ports (Bruges, Gent and Antwerp) or larger-scale infrastructures such as highways and railways. Most wind turbines have been installed in the provinces of West Flanders, East Flanders and Antwerp. A map of potential areas for installation of future wind energy turbines in these provinces are shown in Figure 2 (in brown). Note that not all wind turbines (in yellow) are currently installed in these potential areas.

Large-scale biomass facilities (in green in Fig. 2) are mainly located near ports (Gent and Antwerp), because most resources required for biomass energy production are imported from other countries, mainly from France. In Limburg, plentiful agricultural resources available led to the installation of small and medium-scale facilities.
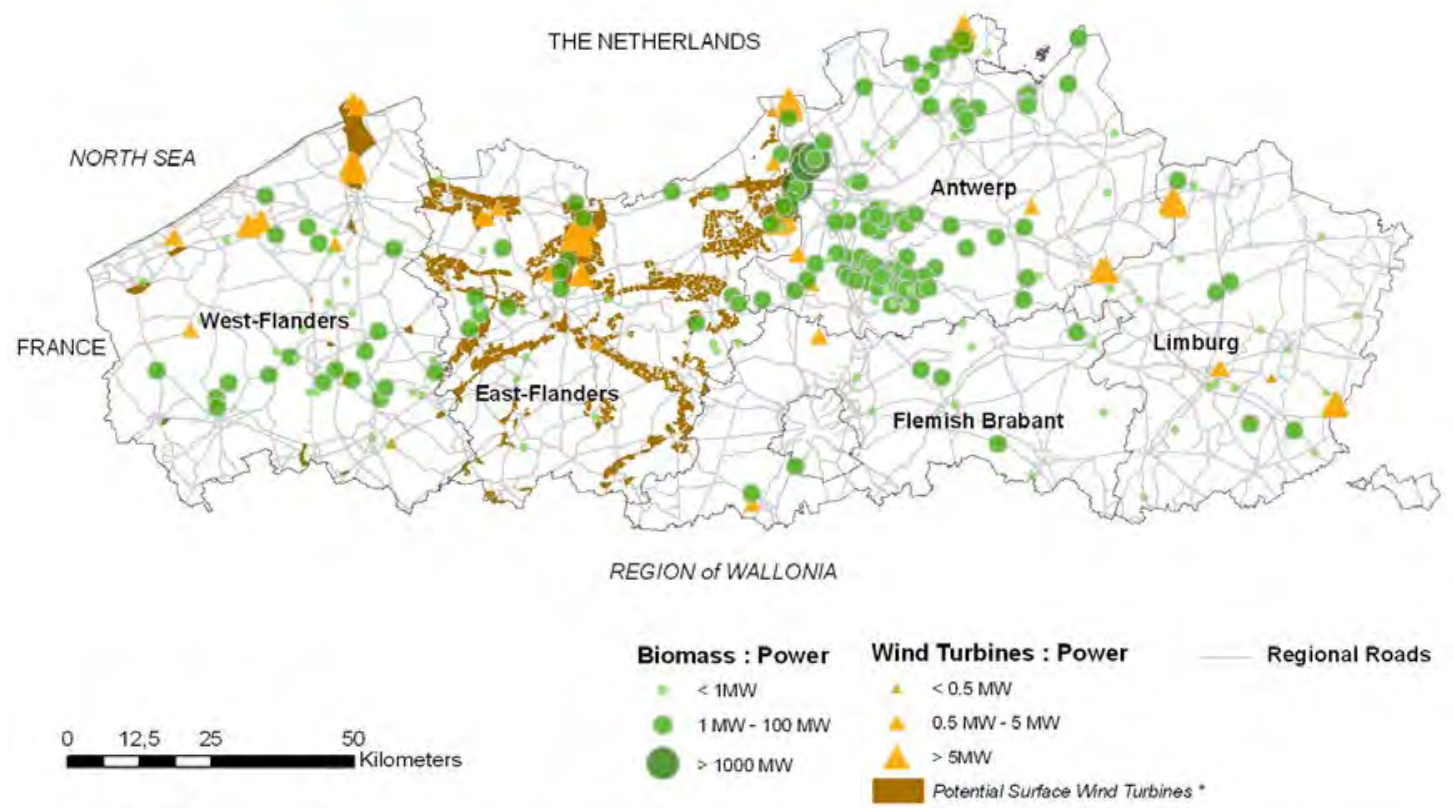

- Only data for Potential Surface are available for the provinces of West-Flanders and East-Flanders. However, potential exist in the other provinces too

Fig. 2. Location of wind and biomass energy facilities in Flanders.

\subsection{Green Electricity}

The share of electricity from RES in total electricity consumption has increased to $3.3 \%$ in 1994-2008. Absolute values increased from $58 \mathrm{GWh}$ to $1,997 \mathrm{GWh}$ by 2008. According to the Flemish Energy Agency [14], 2,688 GWh of electricity were produced from green energy sources by 2009 (4.8\% of total electricity consumption).

In 1994, the electricity from waste incinerators was the main source (Table 2), but in the last five years, the majority of green electricity comes from biomass [14]. Wind power was the second main source in 1994-2008. Although hydropower increased during this period, its share in the total electricity consumption has decreased. 
Table 2. Evolution of the share of green electricity in total electricity consumption (1994-2008)

\begin{tabular}{ccccccccc}
\hline$\%$ & 1994 & 1996 & 1998 & 2000 & 2002 & 2004 & 2006 & 2008 \\
\hline Biomass & - & - & - & - & 21.8 & 31.1 & 56.4 & 54.8 \\
Wind & 15.6 & 11.6 & 8.8 & 9.1 & 17.1 & 15.2 & 16.6 & 16.7 \\
Waste & 78 & 69.2 & 77.9 & 77.4 & 42.5 & 21.6 & 14.5 & 13.4 \\
Biogas & 3.6 & 16.1 & 11.9 & 12.1 & 17.7 & 31.8 & 12.1 & 13.3 \\
Solar & - & - & - & 0.1 & 0.2 & 0.1 & 0.2 & 1.7 \\
Hydro & 2.8 & 3.1 & 1.4 & 1.3 & 0.8 & 0.3 & 0.1 & 0.2 \\
\hline
\end{tabular}

In absolute terms, green electricity from biomass, wind, solar and hydro energy increased 1,331 times during 2002-2008. Biomass has been responsible for over $80 \%$ of green electricity since 2004, especially the selectively collected waste biomass (Fig. 3). In 2009, the electricity generated by biomass $(2,160 \mathrm{GWh})$ represented $80.4 \%$ of the total amount of RESelectricity (2,688 GWh).

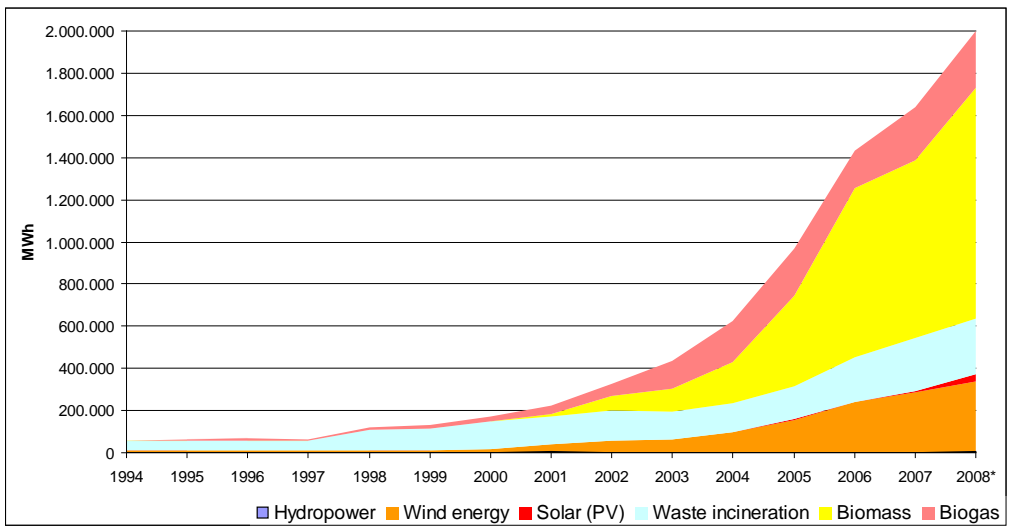

Fig. 3. Evolution of green electricity in Flanders from 1997 to 2008[16].

The largest increase was experienced by electricity from solar energy (6.7 times), but by 2008 it still only represented $1.7 \%$ of the total amount of green electricity. Wind energy, which provides almost $17 \%$ of the total green electricity production, increased by $750 \%$ in $2002-$ 2008 (Fig. 3). In 2009, electricity from solar energy increased steeply to $138 \mathrm{GWh}$ of the 2,688 GWh total green power produced (5\%). Almost 3 million $\mathrm{m}^{2}$ of solar panels for electricity production were installed. Moreover, $100,000 \mathrm{~m}^{2}$ of solar collectors for heat production supplied sanitary water heating for 25,000 Flemish families.

\subsection{Green Certificate System}

The Flemish Region launched a Green Certificate System (GCS) on 1 January 2002. There are two kinds of green energy certificates, compulsory and optional EUR [14]. From 1 January 2002, all electricity suppliers are required to sell a minimum amount of energy from renewable sources. Strong growth of Flemish RES electricity generation from $0.8 \%$ of electricity sales in 2002 to $4.9 \%$ in 2007 brought the 2010 6\% target within reach (Verbruggen, 2009) [17]. The number of Green power certificates issued in 2002-2007 has increased almost 18 times. The technology with the largest increase is PV, from five certificates in 2002 to 139,489 in 2009. This success is a consequence of high certificate prices in the first years of the system. The number of energy certificates decreased last year due to their lower prices (2,692,904 in 2009 and only 929,792 as of July 2010).

The GCS works better than traditional subsidies and is a relatively good option for developing renewable energies. The system achieved relatively good results right from the start, 
especially in promoting the installation of wind turbines and PV solar panels. However, the overall performance of the Flemish support system (effectiveness, efficiency and equity) is assessed as poor, despite its good short-term targets, costs and profits [17]. Moreover, there are no clear transition trajectories to a sustainable power system, and RES electricity generation from old waste-processing facilities is of dubious quality (effectiveness). Moreover, dynamic efficiency is spurious because there is no link to a technological industrial policy (efficiency). Finally, the polluter-pays principle is not respected, but jeopardized in the waste management sector (equity).

\section{Flanders and EU Benchmarking - Main Indicators}

Denmark, Sweden, Finland, Germany, the Netherlands and Austria all made a great effort to reach their EU targets. Flanders had only a of $1.7 \%$ share of green electricity from RES in its total electricity consumption by 2005 (Fig. 4), and was still far from reaching the EU target (6.0\%) for 2010. However, the whole country of Belgium had a 2.8\% share by 2005, and if past performance could be continued in 2005-2010, the EU target would be reached by 2010 (5.3\% in 2008).

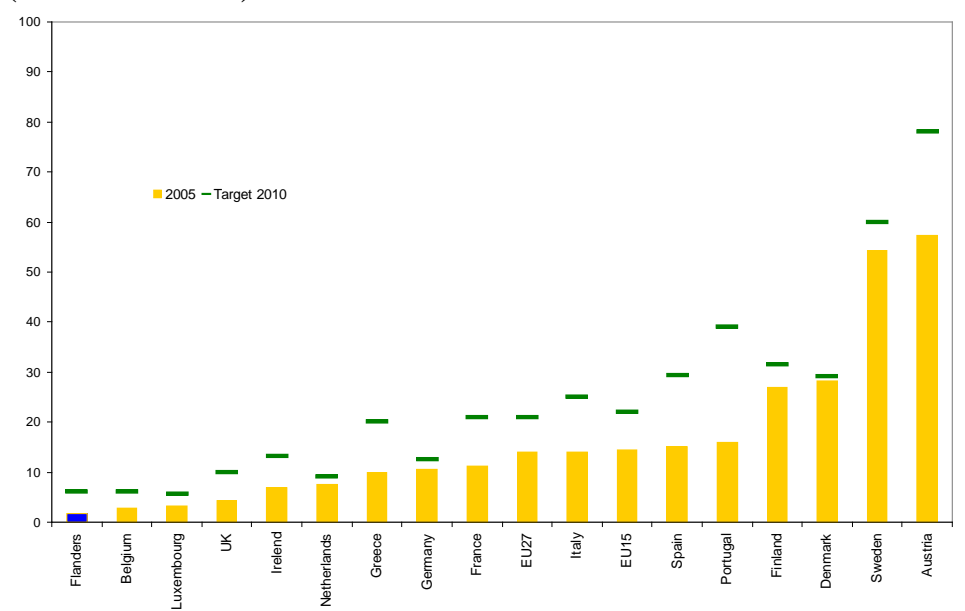

Fig. 4. 2010 EU electricity targets vs. 2005 green electricity production in Europe and Flanders (\%).

The share of RES in Gross Inland Consumption in Flanders is small compared to the other EU countries. The relative share of RES-electricity in Flanders is half the relative share of all of Belgium. This means that the Walloon Region produces roughly 3 times more electricity from RES than Flanders. According to some experts interviewed in this study, this difference between the two regions is explained by the greater availability of biomass resources in the Walloon Region. Moreover, the relative Flemish share is only larger than the relative share of Estonia and Cyprus. In spite of this, the significant increase in its share from $0.21 \%$ in 2004 to 1.22\% in 2007 highlights the effort made by the Flemish Government.

Of the different RES, biomass is the largest in both Flanders and all of Belgium. The share of biomass in Flemish RES production (82.3\%) is the second largest in the EU after Hungary. The share of wind energy in Flanders is also relatively large (17,2\%), and close to the EU27 share (19.8\%). Electricity production from other sources (hydropower, solar and geotechnical) makes up less than $1 \%$ and is relatively insignificant.

\section{Analysis of the Opportunities and Problems related to Spatial Planning}

In the Flemish Region, the development of large-scale energy facilities is mainly limited by its high-density population and related factors, such as concentration of cities and infrastructures (roads, railroads, housing, factories, industrial areas, etc.). Other restricting 
factors are landscapes values, relief (mainly in hydropower facilities), monuments, natural protected areas, air-restricted areas, and so on. Finally, the aesthetics of renewable energy facilities is an important factor related to public acceptance.

The "Projections on renewable energy and cogeneration to 2020" study [18] examined the potential of different technologies (electricity, heat and biofuels), and compared a business-asusual scenario (BAU) with a Pro-active policy (PRO). The Flemish Government used the calculated potential in the PRO scenario in its Energy Plan (Table 3).

Table 3. Potential of renewable energies in Flanders.

\begin{tabular}{cccc}
\hline Technology & $2010(\mathrm{GWh})$ & $2020(\mathrm{GWh})$ & Increase (\%) \\
\hline Wind onshore & 521 & 1,905 & 265 \\
Wind offshore & 320 & 3,841 & 1,100 \\
Solar energy (PV) & 174 & 935 & 437 \\
Solar thermal & 224 & 1,193 & 433 \\
Biomass plants for electricity production & 97 & 217 & 124 \\
\hline
\end{tabular}

In order to realise the potential of renewable energies in Flanders, the surface required for the installation of new facilities is calculated as follows. To reach the target of 1,000 MW, 300 new 2.5-MW wind turbines (+750 MW) are necessary. Since the current legislation prescribes a minimum buffer distance of $250 \mathrm{~m}$ from any dwelling (radius $=250 \mathrm{~m} \rightarrow$ area $=20 \mathrm{ha}$ ), a surface free of housing of 6,000 ha is required.

To reach the proposed $935 \mathrm{GWh}$ by 2020 , VITO $^{\circ}$ assumes that the efficiency of solar panels will improve from the current $110 \mathrm{kWh} \mathrm{m}^{-2}$ per year to $170 \mathrm{kWh} \mathrm{m}^{-2}$ per year. Therefore, an additional 800 ha are necessary to install the required panels. An increase in surface of 300 ha for installing solar water heaters is desired by 2020. However, the installation of PV and thermal panels does not require the acquisition of new land, which makes it a good option.

The main environmental problems related to biomass and CHP facilities are the emissions of greenhouse gases (GHG) and the effect of noise and smell, in addition to the visual impact. Therefore, rural areas are the most suitable for the installation of biomass and CHP facilities. For such an installation, the availability of resources and connection to the power grid are essential. Heat facilities have been observed to be the most used in the rural areas. A regulation related to the use of biomass sources (especially pellets) is needed.

Wind turbines have been installed near large structures, such as industrial areas and highways, and near high power grids. The choice of such locations helps reduce the visual impact and the problem of the noise of wind energy turbines. Most past installation projects were medium or small scale (3-4 turbines) because of existing limitations (mainly the available surface). Nowadays, small wind turbines are considered inefficient. The Windplan for Flanders was launched in 2001.It includes potential areas for the installation of wind turbines according to their wind potential way, the provinces of West Flanders, East Flanders and Antwerp made a more advanced multiple-criteria map of potential areas for the installation of wind energy turbines (residential and industrial areas, protected landscapes, agricultural areas, recreational areas). However, these areas are only designated as suitable, and the map is not legally binding.

The installation of solar panels (at small and medium-scale) has seen a boom in the last year, mainly due to its promotion by the GCS and benefits for private promoters. PV panels are the 
most widespread. The installation of large-scale projects in Flanders (4-6 ha) is generally restricted by the limited availability of surface. The most suitable area for the installation of solar panels in Flanders is the North Sea coast (West Flanders Province). East of the Flemish region, the potential is reduced due to the proximity of higher lands and increased presence of clouds. Belgium is now the 6th most solar PV- intensive country in the world (defined by $\mathrm{km}^{2}$ of solar panels).Price is the main limiting factor for installation of solar panels. Arestricting technical factor is the shadowing by nearby buildings. Around a $20 \%$ shadow on one solar panel suffices to stop the energy production of all the panels connected in the same loop.

\section{Conclusions: Trends and Future challenges of RES in Flanders}

The electricity generation is currently the main application of renewable energies, while heat production (from heat pumps, wind, geothermal, solar) has the highest potential for further application and development in Flanders. There are currently no concrete projects for developing geothermal energy. Should this be reconsidered, more effort by the regional government will be needed to develop this type of RES in the coming years.

The Flemish Government promotes RES through their green certificate pricing policy. First, wind facilities were promoted, followed by PV installations, and more recently biomass and CHP installations. With theses mechanisms, the Flemish Government strives to reach the EU 20/20/20 energy targets. However, a stronger effort to regulate the green energy market and to decrease the cost of kWh produced is necessary, because there are no clear transition trajectories to a sustainable power system. This situation requires broad agreement between the government, the power industry and the public. The RES market potential may be substantially increased by means of dedicated policies, implemented after consensus, such as, a better qualification system, different subsidies, levies and taxes to shift market prices, lowering the cost of RES, or helping abolish man-made barriers through technological innovation. But support for the development of RES through a modified or better GCS must continue in order to reach the EU targets and real sustainable development.

Benchmarking of relative Flanders and EU RES and RES-electricity consumption indicators shows that most of them are low. Despite this, increase in recent years has been significant and highlights the effort made by the Flemish Government.

Concerning spatial planning, the search for available suitable areas to install such facilities must be a priority for renewable energy policy makers. Ports, highways and industrial zones are priority areas for the installation of wind energy facilities. However, a more participatory approach for the development of renewable energy facilities is necessary, especially for the construction of wind turbines.

The large increase in PV solar energy production is accompanied by problems between producers and distribution companies, and further regulation is required in this field. In addition, a better distribution grid is needed, since the current grid is not well adapted to receive all the renewable energy produced.

In addition, the specific potential and conditions of each individual region should be considered when setting regional prices for green certificates, and installation of renewable facilities in areas with lower potential should be promoted (e.g., wind energy in BrabantFlanders and Limburg ). These measures would help decentralise energy production, bring production closer to consumers and avoid grid losses from long-distance energy transport. 
Finally, better regulatory framework co-ordination between governmental departments and the energy is required for the EU, Belgian and Flemish targets to be met.

\section{References}

[1] A.M. Omer, Energy, environment and sustainable development, Renewable and Sustainable Energy Reviews 12, 2008, pp. 2265-2300

[2] I. Dincer, Environmental impacts of energy, Energy Policy 27, 1999, pp. 845-854.

[3] W.W.S. Charters, Developing markets for renewable energy technologies, Renewable Energy 22, 2001, pp. 217-222.

[4] F. Abulfotuh, Energy efficiency and renewable technologies: the way to sustainable energy future, Desalination 209, 2007, pp. 275-282.

[5] IPCC, Climate change 2001, UN International Panel on Climate Change, 2001.

[6] A. Verbruggen, M. Fischedick, W. Mooma, T. Weir, A. Nadaï, L.J. Nilsson, J. Nyboer, J. Sathaye, Renewable energy costs, potentials, barriers: Conceptual issues, Energy Policy 38(2), 2010, pp. 850-861.

[7] DEFRA, Energy Resources, Sustainable development and environment, 2002.

[8] EU, Green paper on an energy strategy for sustainable, competitive and secure energy, COM (2006) 0105.

[9] EU, Green paper on energy efficiency or doing more with less, COM(2005), 265 final.

[10]European Communities, Communication from the Commission to the European Council and the European parliament - An energy policy for Europe, COM(2007)1 final.

[11] Council of the European Union, Brussels European Council 8/9 march 2007, Presidency conclusions, (7224/1/07).

[12]D. Bouquet, T.B. Johansson, European renewable energy policy at crossroads-Focus on electricity support mechanisms, Energy Policy 36, 2008, pp. 4079- 4092.

[13]European Parliament and European Council, Directive 2009/28/EC of the European Parliament and of the Council on the promotion of the use of energy from renewable sources amending and subsequently repealing Directives 2001/77/EC and 2003/30/EC.

[14] Vlaams Energieagentschap, 2010, Available on: http://www.energiesparen.be/

[15]K. Briffaerts, E. Cornelis, T. Dauwe, N. Devriendt, R. Guisson, W. Nijs, S. Vanassche, Prognoses voor hernieuwbare energie en warmtekrachtkoppeling tot 2020. Studie uitgevoerd in opdracht van: Vlaams Energie Agentschap. 2009/TEM/R/. VITO.

[16]E. Cornelis, K. Aernouts, S. Van Geel, WKK-inventaris in Vlaanderen 2008. Studie uitgevoerd in opdracht van: 2009/TEM/R.

[17]A. Verbruggen, Performance evaluation of renewable energy support policies, applied on Flanders’ tradable certificates system, Energy Policy 37(4), 2009, pp.1385-1394.

[18] Vlaamse instelling voor technologisch onderzoek, Prognoses voor hernieuwbare energie en warmtekrachtkoppeling tot 2020. Tussentijds Rapport. Studie uitgevoerd door Vito in opdracht van het Vlaams Energie Agentschap, 2009. 